\title{
Overlooked Geomorphological Component of Volcanic Geoheritage-Diversity and Perspectives for Tourism Industry, Pogórze Kaczawskie Region, SW Poland
}

\author{
Piotr Migon $^{1} \cdot$ Edyta Pijet-Migoń $^{2}$
}

Received: 19 January 2015 / Accepted: 11 November 2015 / Published online: 23 November 2015

(C) The Author(s) 2015. This article is published with open access at Springerlink.com

\begin{abstract}
In the West Sudetes (SW Poland), volcanic activity of Oligocene and Miocene age has left a suite of landforms of considerable geomorphological interest. Besides being relevant to the subject of volcanology, they illustrate how volcanism influences interplays with landscape development in the long-term. Three main geomorphological themes are explored: structural geomorphology of ancient volcanic terrain, volcanic remnants as markers of long-term denudation and hillslope evolution under periglacial conditions of the Pleistocene. Volcanic geosites are used as a resource for geotourism and promotion of geoheritage has intensified recently, with the region branding itself as the 'Land of Extinct Volcanoes'. Ten localities are evaluated as geomorphosites of significant educational potential, taking into account geomorphological values, added values as well as physical accessibility and information supply. Successful interpretation remains a key challenge in further geotourism development, and several associated practical issues are pointed out such as choice of terminology, uncertainties in scientific understanding and stand-alone attractiveness of geoheritage.
\end{abstract}

Keywords Cenozoic volcanism · Geomorphosites · Geosite assessment $\cdot$ Geotourism $\cdot$ Sudetes

Piotr Migoń

piotr.migon@uni.wroc.pl

1 Institute of Geography and Regional Development, University of Wrocław, pl. Uniwersytecki 1, 50-137 Wrocław, Poland

2 Wrocław School of Banking, Institute of Tourism, Fabryczna 29-31, 53-609 Wrocław, Poland

\section{Introduction}

Volcanic events and volcanic landforms represent natural phenomena which have long generated considerable interest amongst both scientists and general public, with examples appearing since the antiquity (Erfurt-Cooper 2010, 2014). Today, fascination with volcanism is exemplified by countless publications, scientific and popular science alike, dedicated websites, museums and exhibitions, marked volcanic trails, etc. Many volcanoes or their groups, with associated geothermal phenomena and often curiously shaped landforms, are considered as the most valuable national heritages and protected in national parks and nature reserves. The World Heritage List of UNESCO now lists at least 16 volcanic sites (Wood 2009; Badman 2010), making contemporary volcanism the most represented theme amongst all Earth science themes (Dingwall et al. 2005). Numerous European geoparks, whether within the European Geopark Network or designated at a national level, explore volcanic themes, both ancient (e.g. Petrified Forest on Lesvos, Greece; Egeria, Germany; Góra Świętej Anny, Poland) and more recent (Eifel, Germany), as well as contemporary volcanism itself (Katla, Iceland; El Hierro, Spain). Likewise, several global geoparks have been established in areas of either contemporary/sub-recent volcanism (e.g. Unzen and Aso, both in Japan; Wudalianchi, China; Batur, Indonesia) or with significant palaeovolcanic heritage (e.g. Hong Kong Geopark). Volcanic terrains feature prominently amongst National Parks and National Monuments in the USA, including such iconic sites as Crater Lake, Devil's Tower and Hawaii Volcanoes.

However, a closer examination of available information about these and other volcanic sites shows that the main focus tends to be on eruptive processes, geotectonic context and petrological diversity of volcanic materials. The geomorphological component of volcanism is less emphasised and 
explored, despite its huge role in transforming pre-existing landscapes (see Ollier 1969) and extreme landform diversity associated with the active volcanic terrains (Thouret 1999). Volcanic rocks and structures can be also used as useful markers of long-term geomorphological change. In Scotland, Hall (1991) used the contemporary setting of early Tertiary volcanics to estimate the magnitude of long-term erosion and relief inversion. In southwest USA, dating of lava flows and cinder cones of Miocene to Quaternary ages helped to constrain the likely rates of formation of variable geomorphic features such as pediments, desert pavements and drainage lines (Dohrenwend et al. 1986). In Hungary and Romania, post-eruptive evolution has been deciphered for a number of volcanic features of Miocene age (Karátson 1996; Németh and Martin 1999; Karátson et al. 2001), and more recently, a similar research avenue is being explored in the Czech Republic (Rapprich et al. 2007), Poland (Awdankiewicz 2005) and Germany (Buchner and Tietz 2013), all close to the area presented in this paper. Furthermore, dormant volcanoes can be used as natural laboratories to monitor post-eruptive geomorphological change (e.g. Parícutin in Mexico, see Inbar et al. 1994).

Whilst a number of recent publications focused on volcanic heritage implicitly addresses volcanic geomorphology, demonstrating its key contribution to both scenic quality and scientific significance of areas of recent and sub-recent igneous activity (Gao et al. 2013; Moufti and Németh 2013; Boivin and Thouret 2013), sites of more ancient (pre-Quaternary) and long extinct volcanism usually remain unexplored in geomorphological context. One of a few notable exceptions is the Causeway Coast in Northern Ireland, where multiple lava sheets of early Palaeocene age are exposed along the coastal cliffs. They are separated by inter-basaltic horizons which are essentially ancient ferrallitic weathered mantles. Dating of underlying and overlying basalt allowed geoscientists to obtain insights into rates of weathering front descent and basalt alteration under humid and warm climatic conditions (Smith and McAlister 1987; Hill et al. 2001). The presence of distinctively red inter-basaltic beds within otherwise dark basaltic cliffs is highlighted as one of the main features of interest at the site and elaborately explained, although Crawford and Black (2012) noted that visitors were not fully satisfied with the level of interpretation provided.

The purpose of this paper is to demonstrate the geomorphological significance of sites of past Cenozoic volcanism located in south-west Poland, specifically in the region of Pogórze Kaczawskie (Kaczawskie Upland). Many of these localities have been extensively studied in geological and geochronological context, and it is mainly this kind of information that has been transferred into popular science and geoeducation domains. Their geomorphological dimension remains overshadowed and the principal aim of this paper is to redress the balance in a specific geoheritage context. To do so, two interrelated themes will be explored: the geomorphology of volcanic remnants itself as well as past, present and future initiatives towards the popularisation of volcanic heritage, along with associated challenges and opportunities. Since much of geoscience outreach is carried out at geosites, special attention will be paid to localities which best fit the definition of geomorphosites (Reynard 2009) and link natural and cultural heritage (Panizza and Piacente 2009).

\section{Study Area and Volcanic Past of South-West Poland}

\section{Regional and Geochronological Context}

The study area encompasses the northern part of the Sudetes, which themselves are a mountain range located in the northeastern portion of the Bohemian Massif in Central Europe (Fig. 1). The Sudetes belong to the belt of peri-Alpine Variscan orogens, rejuvenated in the Cenozoic through differential uplift and subsidence of rigid crustal blocks along numerous fault lines (Zuchiewicz et al. 2007; Reicherter et al. 2008), and further modified by rock-controlled selective denudation (Placek and Migon 2007). As a consequence, the contemporary Sudetes are a mosaic of mountain massifs, ridges, uplands and intramontane basins, with a great diversity of medium-size and minor landforms.

In the geological history of the Sudetes, volcanism occurred repeatedly (Table 1). Three principal periods of volcanic activity are distinguished and broadly dated for early Palaeozoic (Cambrian-Silurian), Carboniferous-Permian and Cenozoic (Badura and Przybylski 2004). The oldest period was typified by submarine eruptions and effusions. These ancient lava flows have been changed into greenschists during the Variscan orogeny, although locally retain original pillow lava appearance. Distant age and subsequent burial and metamorphism preclude the possibility for any element of original effusive morphology to survive, and hence, greenschist complexes are of limited interest in the context of this study.

Late Carboniferous and early Permian were time spans of vigorous volcanic activity in the Sudetes, mainly within two major post-Variscan subsidence areas, the Intra-Sudetic Basin (ISB) and the North-Sudetic Basin (NSB). Late Palaeozoic volcanism was bimodal (basic to acidic) and highly diversified in terms of mode of emplacement and/or eruption. Its legacy includes simple and compound rhyolitic domes, lava flows, remnants of trachyandesitic shield volcanoes, ignimbrite sheets, diatremes and calderas (Awdankiewicz 1999). The peak of eruptive activity in the Autunian was followed by a considerable increase of sediment fluxes from source areas to basins in the Saxonian (Blecha et al. 2008), and it is likely that any remaining volcanic landforms became buried under younger clastic sediments. Subsequent (Tertiary?) differential weathering and erosion re-exposed volcanic bodies which 


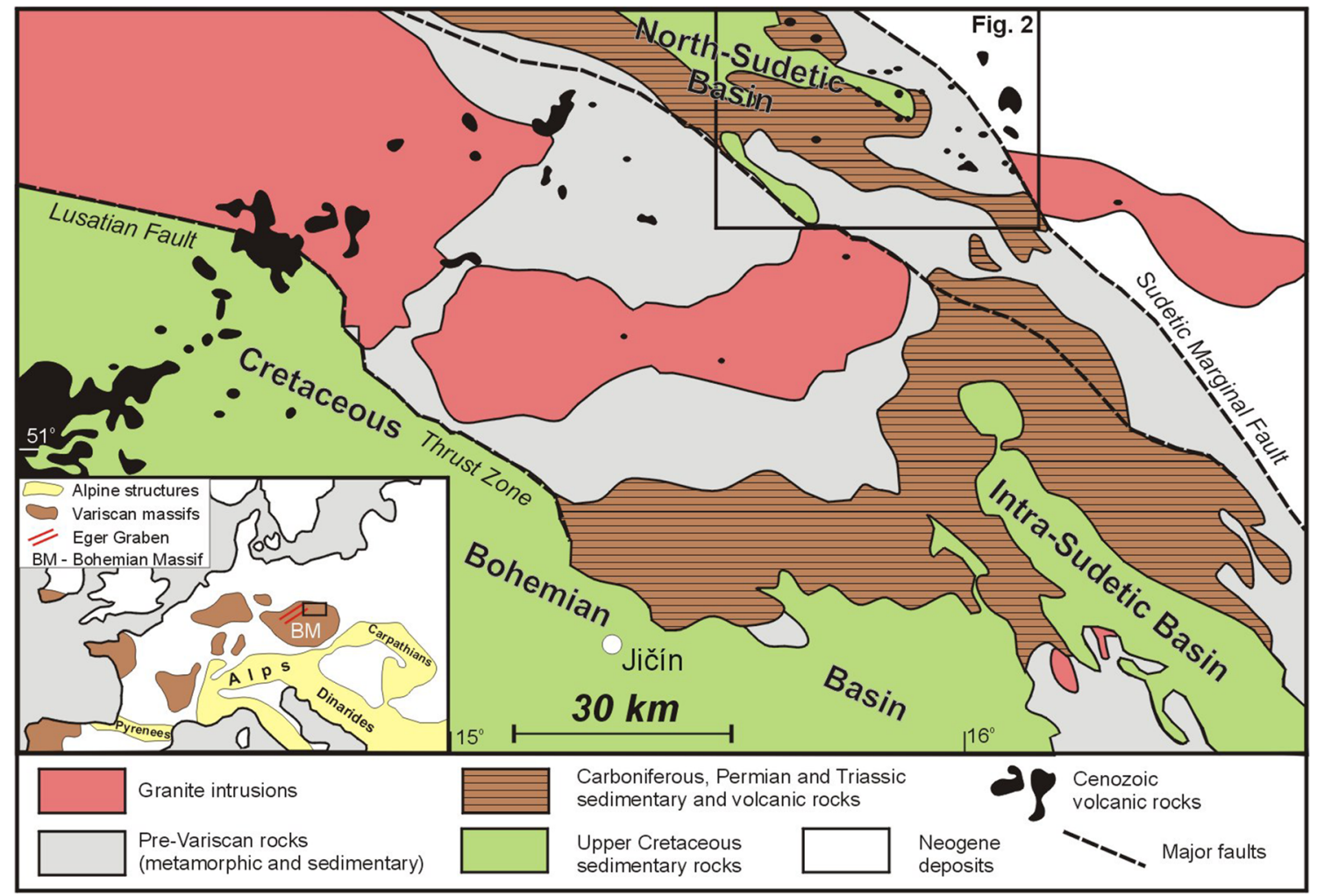

Fig. 1 Geological structure of the West Sudetes. Inset shows the position of the study area within Europe and the Bohemian Massif. Many small basalt outcrops are not indicated on the map

now invariably form higher ground. In the ISB, the height of rhyolite domes and trachyandesite ridges locally approaches $400 \mathrm{~m}$, whereas in the NSB, the respective figure is $150 \mathrm{~m}$. Scientific and scenic values of Carboniferous and Permian volcanic outcrops in the ISB, including their impressive morphology, have been emphasised in the context of geoheritage protection and the possible setting up of a geopark (Kosiór 2004; Ihnatowicz et al. 2011).

Cenozoic intraplate volcanism commenced in the latest Eocene and reached its peak in the late Oligocene and early Miocene, declining afterwards (Badura et al. 2005; Birkenmajer et al. 2007). Altogether, more than 300 surface occurrences have been recorded in south-west Poland, with the overwhelming majority in the north-western, less elevated part of the Sudetes. Many more are known from boreholes to occur beneath Neogene deposits (Cwojdziński and Jodłowski 1982) or are suspected from geophysical surveys. Collectively, they are called the 'Lower Silesian Basaltic Province', although the volcanics are not necessarily all basalts and different rock types have been identified, including basalt s.s., nephelinite, basanite, phonolite, tephrite and many others. However, this generic name will be used in this paper, unless specifically mentioned. The 'province', in turn, is the easternmost extension of the Central European volcanic belt which stretches from the Rhine Graben through Germany and northern Czech Republic into Poland (Kopecký 1978). Comparison of age determinations of Cenozoic volcanic rocks and the history of sedimentation around the Sudetes indicates that volcanism largely preceded the main period(s) of differential uplift and subsidence of rejuvenated Variscan ranges, inferred to have occurred after the middle Miocene (Ziegler and Dèzes 2007).

\section{Pogórze Kaczawskie Region}

The area considered in detail in this study is located in the north-western part of the Polish Sudetes and, according to the regional geographical division, is called Pogórze Kaczawskie (usually translated as the Kaczawskie Upland or the Kaczawskie Hilly Land). It represents a rolling upland type of relief, with altitudes hardly exceeding $450 \mathrm{~m}$ a.s.l. and the relative relief of the order of $50-100 \mathrm{~m}$ per $1 \mathrm{~km}^{2}$ (Fig. 2). Bedrock includes pre-Variscan metamorphic rocks, mainly greenschists and phyllites, partly overlain by PermoMesozoic sediments of the North-Sudetic Basin, mainly sandstones. The eastern boundary of the area is marked by a distinct mountain front related to the Sudetic Marginal Fault (Migoń and Łach 1998), active since the latest Oligocene (Badura et al. 2004, 2007). In the Quaternary, during the Oxygen Isotope Stage 12, the area was reached and overridden by the Scandinavian ice sheet (Badura and Przybylski 1998), which left behind a thin cover of glacial and outwash deposits. 
Issues of the possible existence of nunataks at the time of maximum ice extent and the magnitude of glacial erosion in the ice-marginal terrain have been debated and are far from being unequivocally solved (Migoń et al. 2002).

\section{Geoconservation of Volcanic Heritage}

Although the Sudetes are amongst the most diverse parts of Poland in terms of both geological and geomorphological heritage, conservation has long been focused mainly on biotic components and geological sites of interest were either neglected or protected indirectly, i.e. within national parks, landscape parks and nature reserves which were set up for different purposes (Alexandrowicz et al. 1992; Gawlikowska 2000). However, sites of Cenozoic volcanism in the Pogórze Kaczawskie were a notable exception, even if the primary reason of protection was not always geological or geomorphological legacy. Nature reserves exist on three basalt outcrops, Mt Wilkołak (since 1959), Mt Ostrzyca (since 1962) and Muchowskie Wzgórza (since 2015), with the former established explicitly to conserve a unique outcrop of columnar jointing in basalt. Another two outcrops of impressive columnar jointing, at Mt Czartowska Skała and Mt Rataj, are protected as nature monuments. Finally, nearly the entire eastern part of the Pogórze Kaczawskie region is included in the 'Chelmy' Landscape Park (established in 1992), and volcanic heritage has been given due prominence since its setting up.

\section{Geomorphological Themes in Cenozoic Volcanism of the Pogórze Kaczawskie Region}

\section{Volcanic Structures}

Cenozoic volcanism in the Sudetes occurred in a variety of styles. Three main types are distinguished (Birkenmajer 1967): (a) central eruptions which produced singular volcanic cones of different size and internal structure, from lava-dominated shield volcanoes to cinder cones and maars. Depending on the level of erosional truncation, volcanic bodies observed today are interpreted as nearsurface plugs or deeper vents, (b) fissure effusions leading to lava flows and laterally extensive lava sheets and (c) subvolcanic dykes and sills, usually of limited thickness of a few metres. Types (a) and (b) are of main interest here since they support more or less distinctive landforms today, whereas dykes and sills show poorly in the landscape, likely because of their small size. However, to the south of the Sudetes, in the Czech Republic, some basaltic dykes have been exposed by long-term erosion to form continuous rock walls, sharply contrasting with the adjacent gentle slopes.

The inner structures of volcanic bodies could have only been recognised from quarry exposures, which abound in the region, both disused and currently in operation. By contrast, natural exposures are generally scarce and those which occur are rather small (tens of metres long at most), offering 
Fig. 2 General morphology of the Pogórze Kaczawskie area shown through the shaded relief model and geomorphic setting of major volcanic outcrops (triangles) of Cenozoic age. Numbers according to Table 2. Sites subject to geomorphosite assessment are named. Triangles are located adjacent to basalt hills in order not to interfere with their surface expression

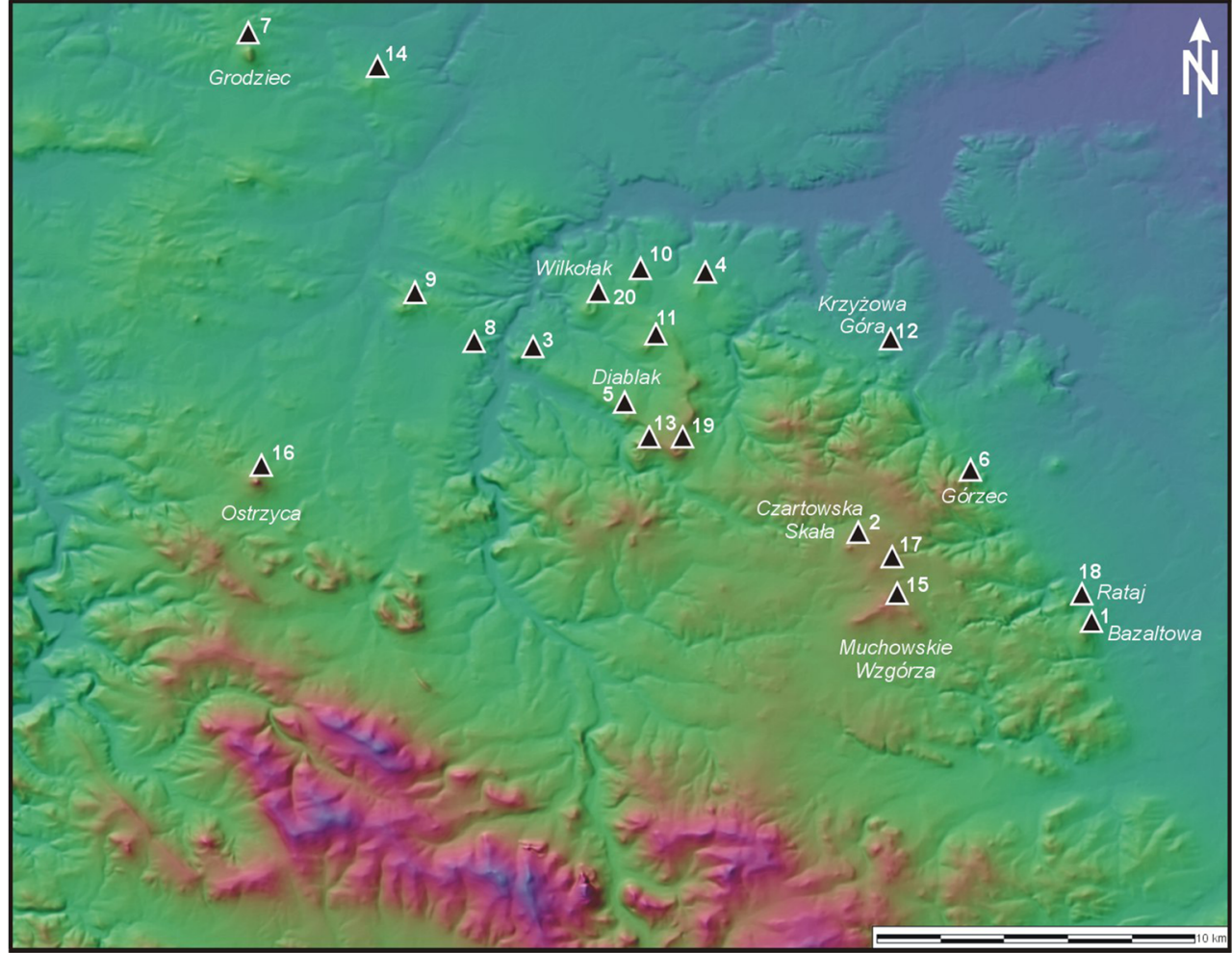

limited insights into the anatomy of former volcanoes. Therefore, if a quarry is absent, the nature of the volcanic body usually remains uncertain. Thus, Birkenmajer's (1967) description of numerous sites of Cenozoic volcanism as nature monuments was almost exclusively based on quarry observations.

Columnar jointing is a characteristic feature of many outcrops of Cenozoic volcanics. Jointing geometries vary from simple fan-like patterns characteristic for single-phase activity in a small vent to complicated, multi-phased structures with various cross-cutting relationships and eye-catching arrangements of 'basaltic roses' (Birkenmajer 1967; Śliwa 1967). In lava flows, vertical colonnades have developed, sloping outward in their marginal parts.

Another object of geological interest are country rock xenoliths contained by Cenozoic volcanic rocks. These are derived from either substantial depth and represent the basement, giving insights into the geological structure at depth (Puziewicz et al. 2011), or from a long eroded sedimentary cover. The latter are of particular interest for geomorphology, as will be shown later.

\section{Rock-Controlled Landforms in Ancient Volcanic Terrain}

\section{Basalt Hilly Morphology}

In the present-day morphology of the West Sudetes, including the Pogórze Kaczawskie region, no remnants of Oligocene or Miocene volcanic constructions can be identified, nor solidified lava flows located in their primary position. Ancient volcanic cones are long eroded and contemporary conical or domed hills are built almost exclusively of hard lava solidified at different depths in the former volcanic conduits (Fig. 3). Tuff materials are rare and poorly exposed, unless uncovered by quarrying. The height of basalt hills varies from as little as 20 to $150 \mathrm{~m}$ in the case of the most evident volcanic neck, Mt Ostrzyca $(501 \mathrm{~m})$ (Table 2). The hills differ in shape too, depending on their wider geomorphic context. Some show nearly perfect symmetry, whereas those situated along fault-generated escarpments or cuesta ridges may be distinctly asymmetrical, rising above the upland surface or cuesta dip-slope by less than $20 \mathrm{~m}$ and via a gentle $\left(<15^{\circ}\right)$ slope. By contrast, their opposite slopes are typically inclined by $25-35^{\circ}$.

The invariable association of Cenozoic volcanic rocks with hilly morphology has been interpreted in terms of higher resistance of basalt (Wocke 1927; Birkenmajer 1967; Walczak 1968). However, unequivocal evidence has been lacking until the recent work by Placek (2007). She carried out an extensive programme of rock strength measurements using Schmidt hammer (see Day and Goudie 1977 for a description of the device) and demonstrated that hill height is dependent on two factors. One is hill diameter, hence approximately the area of volcanic rock occurrence in plan, the other being strength difference between volcanic rock (typically $>60$ points on the Schmidt hammer scale for basalt) and the country rock. Heights above $100 \mathrm{~m}$ are reached only if the strength of country rock is less than 42 , whereas with the country rock being as mechanically strong as basalt ( $\sim 60 \mathrm{SH}$ points), the height of 
Fig. 3 Diverse morphology of remnants of mid-Cenozoic volcanoes in the Pogórze Kaczawskie region. a The conical shape of Mt Ostrzyca represents an exposed volcanic conduit- $-\mathrm{a}$ neck. b More rounded shape of Mt Grodziec is a plug. c

Artificially sharpened conical shape of Mt Czartowska Skała. d Muchowskie Wzgórza (Muchów Hills) have very subdued relief, despite being the second highest volcanic elevation in the region
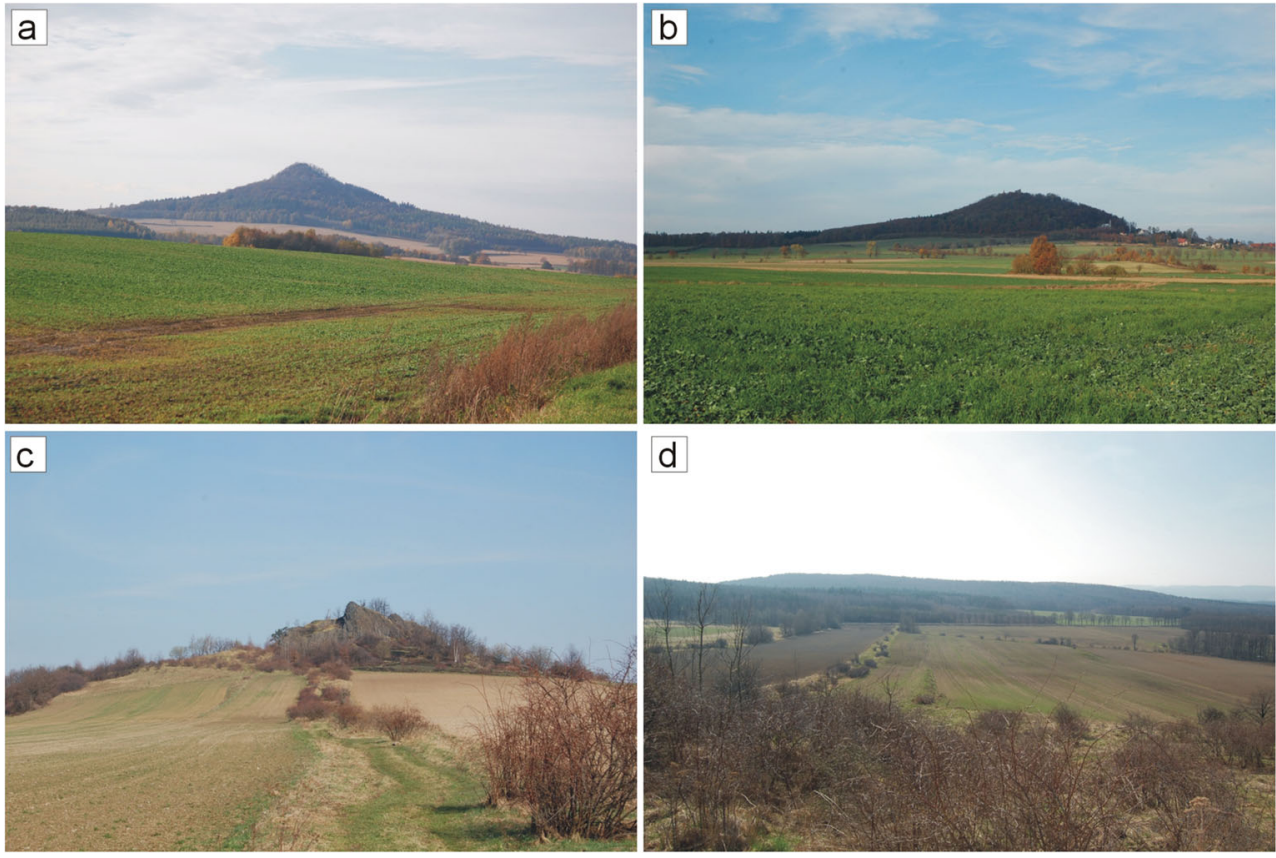

the basalt hill is often less than $30 \mathrm{~m}$. This relationship is particularly valid for small volcanic outcrops $\left(<0.1 \mathrm{~km}^{2}\right)$. Generally, morphological expression of basalts is higher within sedimentary rock terrain, especially if fine-grained Cretaceous rocks (siltstones, calcareous sandstones) occur around a former volcanic conduit. In the eastern part of the Pogórze

Table 2 Characteristics of selected basaltic hills in the Pogórze Kaczawskie area

\begin{tabular}{|c|c|c|c|c|}
\hline Name of the hill & Number (see Fig. 2) & Summit altitude (m a.s.1.) & Relative height $(\mathrm{m})^{\mathrm{a}}$ & Country rock \\
\hline Bazaltowa & 1 & 369 & $109(44)$ & Greenschist \\
\hline Czartowska Skała & 2 & 464 & 84 & Greenschist \\
\hline Czerwony Kamień & 3 & 325 & $120(40)$ & Sandstone (Triassic, Cretaceous) \\
\hline Dębina & 4 & 313 & 53 & Phyllite \\
\hline Diablak & 5 & 391 & $128(49)$ & Sandstone (Cretaceous) \\
\hline Górzec & 6 & 445 & $135(25)$ & Greenschist, phyllite \\
\hline Grodziec & 7 & 389 & 109 & Conglomerate (Permian) \\
\hline Jeziorna & 8 & 293 & $78(38)$ & Sandstone (Triassic, Cretaceous) \\
\hline Kamienna Góra & 9 & 356 & $101(56)$ & Sandstone (Triassic, Cretaceous) \\
\hline Kostrza & 10 & 312 & 52 & Phyllite \\
\hline Kozia & 11 & 375 & $95(40)$ & Sandstone (Cretaceous) \\
\hline Krzyżowa Góra & 12 & 258 & 48 & Phyllite \\
\hline Łysanka & 13 & 444 & $179(44)$ & Sandstone \\
\hline Mnisza Góra & 14 & 310 & 55 & Conglomerate (Permian) \\
\hline Muchowskie Wzgórza & 15 & 475 & 90 & Greenschist \\
\hline Ostrzyca & 16 & 501 & 161 & Sandstone, conglomerate (Permian) \\
\hline Owczarek & 17 & 448 & 38 & Greenschist, phyllite \\
\hline Rataj & 18 & 350 & $90(35)$ & Greenschist, phyllite \\
\hline Trupień & 19 & 481 & $141(81)$ & Sandstone (Triassic, Cretaceous) \\
\hline Wilkołak & 20 & 367 & 102 & Sandstone (Cretaceous) \\
\hline
\end{tabular}

Two values of relative height are given for hills located within cuesta faces or tectonic mountain fronts. They show distinct asymmetry, rising only little above the backslope (the second numerical value, in brackets)

${ }^{a}$ Relative height is obtained by subtracting the lowest altitude present within a radius of $0.5 \mathrm{~km}$ from the summit altitude, except for Muchowskie Wzgórza, where a radius of $1 \mathrm{~km}$ was applied because of large size of the hills 
Kaczawskie, built of early Palaeozoic metamorphic rocks, including massive greenstones, basalt hills are more subdued.

\section{Minor Structural Landforms}

Hillslope morphology of basalt hills provides numerous examples of how structure controls slope evolution and slope processes (Figs. 4 and 5). Basalt bodies often exhibit columnar jointing (Birkenmajer 1967) which, however, occurs in several variants (Śliwa 1967). Columns can be narrow $(<30 \mathrm{~cm}$ across) and regular, or wide and contorted. In certain instances, 'pseudo-columns' are distinguished and these are massive fragments of basaltic lava, separated by vertical joints spaced as much as 1.5-2 $\mathrm{m}$ apart. Columns have different orientations, depending on the position of the original cooling surface and the depth of erosional intersection of the volcanic body (Birkenmajer 1967). In general, pointed cones such as Mt Ostrzyca appear to be associated with dipping columns, whereas quarries cut into subdued domes with gently convex or planar summit surfaces reveal vertical or nearly vertical colonnades (Fig. 6).

A diverse geometry of columnar jointing within one volcanic body bears directly on hillslope morphology. Mid-slope rock cliffs are typically associated with columns inclined into the slope, hence intersecting the slope surface by nearly a right angle (Fig. 5). They are from 2 to $6 \mathrm{~m}$ high, depending on the thickness of the column package, and show a distinct asymmetry. Nearly vertical precipices face downslope, whereas gently inclined ramps connect the crest of a crag with the surface further upslope (Fig. 5a). The morphology of southern and south-eastern slopes of Mt Ostrzyca, one of a few basalt hills in the region not significantly modified by quarrying, best exemplifies the role of columnar jointing in controlling details of hillslope morphology. Here, a dozen or so mid-slope angular tors (spurs) occur at different altitudes, either far from each other, or separated by narrow ravines. Some are built of massive columns, $>50 \mathrm{~cm}$ across, but others show rather thin and less regular shapes, $<30 \mathrm{~cm}$ across. The size of columns, hence joint spacing, is amongst the factors influencing the texture of the talus below and its contemporary stability. Steep non-vegetated blockslopes extend below the most massive spurs, whereas less inclined, partly overgrown debris surfaces co-exist with less distinct crags, but the association is not perfect. Microclimatic factor plays a role too and talus on the shaded, northern and north-eastern side of the hill is almost invariably colonised by vegetation, regardless of the size of the rock spur above.

In the Muchowskie Wzgórza (Muchów Hills) area, the relationships between structure and morphology are different. Interpretation of the original volcanic body is not agreed and a view has been expressed that remnants of a conduit are surrounded by a lava flow (Grocholski and Jerzmański 1975). This view may be supported by the occurrence of massive, vertically arranged columns with clear horizontal platy joints along the morphological axis of the hill. The top part of the ridge is flat, intersecting the columns at right angle, and delimited by vertical rock cliffs on either side (more pronounced on the north though). The cliffs are 3-4 $\mathrm{m}$ high, their lower sections being buried by angular basalt blocks derived from natural outcrop disintegration (Fig. 4d). On the nearby Mt Bazaltowa, characteristic by its extensive planar top surface, no natural rock cliffs occur, but a disused quarry clearly
Fig. 4 Details of hillslope geomorphology of volcanic elevations in the Pogórze Kaczawskie region. a Impressive crags in regularly jointed basalt, more than $10 \mathrm{~m}$ high-Diablak locality. b Bare periglacial block fields and mid-slope crags at Mt Ostrzyca. c Considerably overgrown block slope of $\mathrm{Mt}$ Górzec. d Cliffs and cryoplanation terraces in massive basalt of Muchowskie Wzgórza
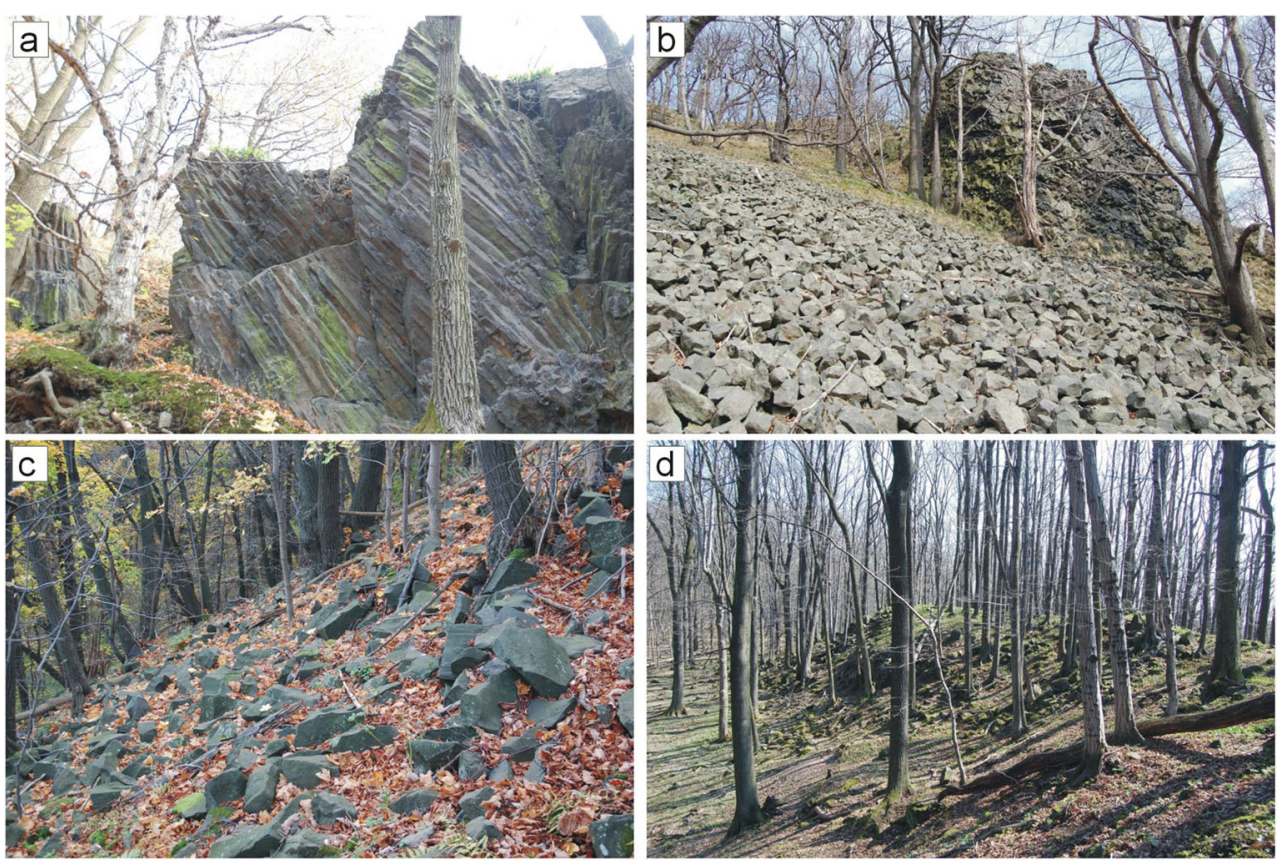


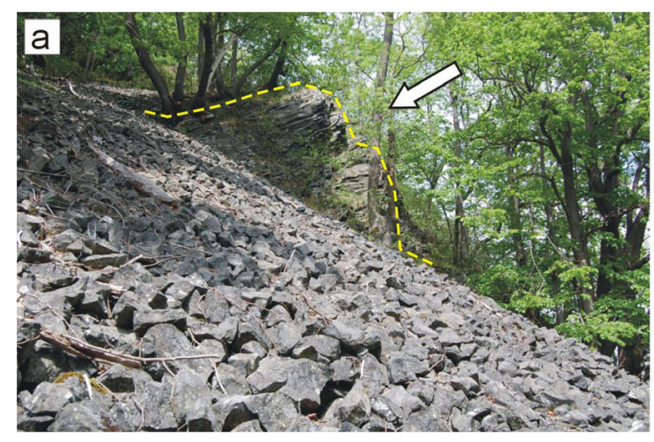

Fig. 5 Structural control of mid-slope crags, highlighted by arrows. a Asymmetry of a rock spur at Mt Ostrzyca (highlighted by the broken line) reflects the dip of columnar jointing into the slope. b Slope cut in an

shows that this surface is underlain by a well-developed colonnade (Fig. 6).

\section{Witnesses and Markers of Long-Term Denudation}

Degraded volcanoes are important witnesses of long-term landscape evolution, including its rates and change through time (e.g. Németh 2001). However, only a few studies exploring this theme have been undertaken in the Sudetes and the surroundings. Recent examples include Awdankiewicz (2005), Rapprich et al. (2007), Tietz et al. (2011) and Büchner and Tietz (2013), although none was carried out in the area considered in this paper. Nevertheless, the study by Rapprich et al. (2007) of middle Miocene volcanic remnants in the Jičín area south of the West Sudetes (see Fig. 1) is highly relevant for two reasons. First, Rapprich et al. (2007) demonstrated that tuff facies are present around basalt bodies and interpreted volcanic hills as degraded cinder cones. Second, they estimated the magnitude of post-eruptive erosion in the Cretaceous siltstone and sandstones as less than $100 \mathrm{~m}$ during c. 17 million years, which is surprisingly low given the mechanical weakness of these sedimentary formations.

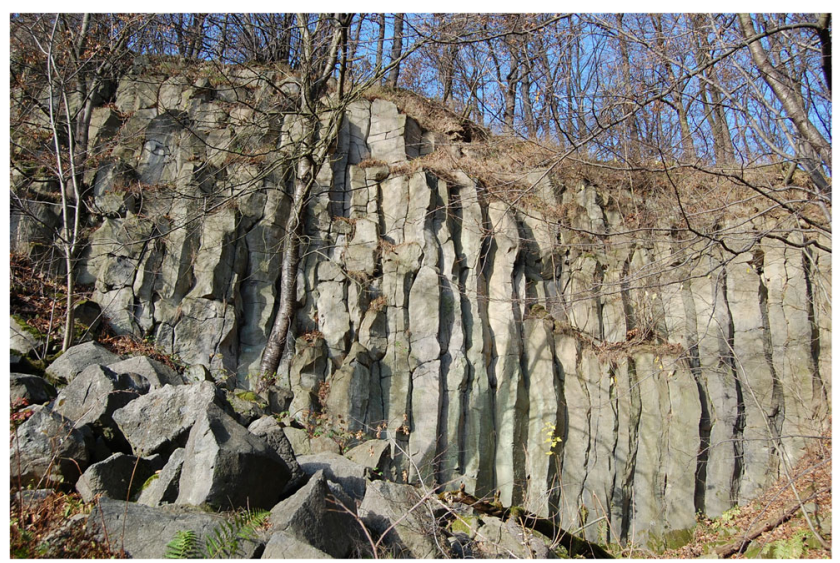

Fig. 6 Basalt colonnade to underlain the flat summit surface of Mt Bazaltowa

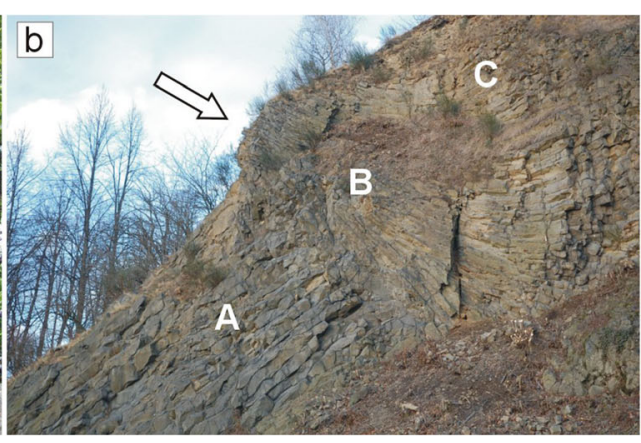

abandoned quarry at Mt Wilkołak shows how the location of mid-slope crag is controlled by a change in orientation of columnar jointing, from slope-parallel (parts $A$ and $C$ ) to slope-perpendicular (part $B$ )

In the Pogórze Kaczawskie region, the potential of volcanic rocks to constrain long-term erosion was first indicated by Zimmermann and Kühn (1936), who noted the presence of Cretaceous sandstone xenoliths in a basalt occurrence near Leszczyna (see Fig. 2). The nearest outcrops of sandstones can be found in a caprock part of a cuesta $1.8 \mathrm{~km}$ to the west, suggesting scarp retreat of at least this magnitude since eruption. The projection of sandstone unit dip indicates that the corresponding surface lowering must have been at least $180 \mathrm{~m}$, involving Upper Permian, Triassic and Upper Cretaceous sediments (Fig. 7). Unfortunately, the highly weathered basalt from this site was not amongst those dated radiometrically by Badura et al. (2005) or Birkenmajer et al. (2007).

The scarcity of pyroclastic deposits associated with basalt occurrences in the West Sudetes suggests more advanced erosion of ancient volcanoes and a deeper level of erosion in the surroundings than that established for the Jičín area (Rapprich et al. 2007). This is not surprising given the considerably older age of eruptive activity in the Pogórze Kaczawskie which peaked in the Oligocene. Furthermore, the area is located close to the active mountain front of the Sudetes, where phases of uplift must have triggered erosion of the hinterland. Finally, ice sheet advance in the middle Pleistocene may have caused glacial stripping of poorly consolidated scoria material, a factor that did not play a role south of the main water divide of the Sudetes, never overridden by the Scandinavian ice sheet except for a few short tongues south of low mountain passes at the German/Czech border.

\section{Periglacial Modelling}

The impact of moving ice on the morphology of basalt hills in the West Sudetes is uncertain and no evident glacial erosion indicators have been identified. By contrast, the legacy of cold climate (periglacial) conditions is clear and has been studied by numerous authors, although the results have been published mainly in Polish (e.g. Baraniecki 1951; Piasecki 1956; Migoń et al. 2002; Maciejak 2010). Periglacial landforms and deposits include scree slopes, frost-riven cliffs, 
W

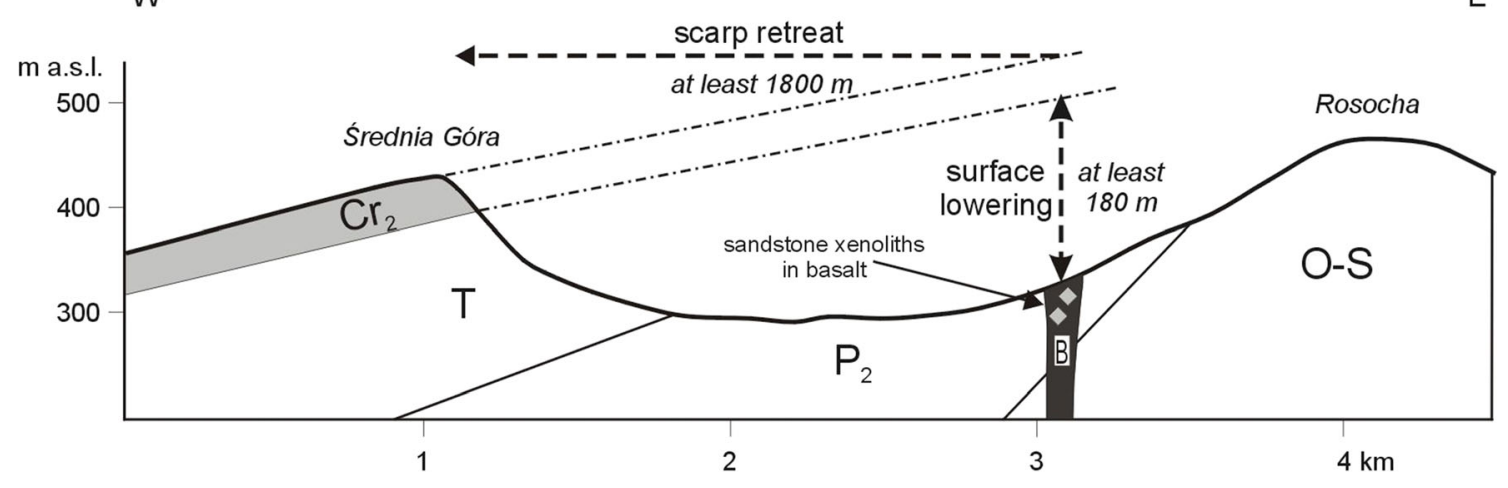

Fig. 7 Long-term scarp retreat and surface lowering inferred from the presence of sandstone xenoliths in a basalt occurrence near Leszczyna, based on the description in Zimmermann and Kühn (1936). Explanation of codes: $\mathrm{O}-\mathrm{S}$ Ordovician-Silurian, $\mathrm{P}_{2}$ Upper Permian, $\mathrm{TTriassic}^{\mathrm{C}} \mathrm{Cr}_{2}$ Upper Cretaceous

cryoplanation terraces, tors, solifluction cover deposits and loess mantles.

Scree slopes at the angle of repose are the most distinct features inherited from the Pleistocene and testify to the high efficacy of mechanical breakdown of basalt in cold environment (Fig. 4b, c). Today, the majority of scree surfaces are colonised by vegetation and only a few remain exposed, usually on south-facing slopes. Scree formation was favoured by moderately dense jointing of basalt (20-30 cm apart), and the best examples occur below rock spurs with exposed columns of roughly this size, as on Mt Ostrzyca. With denser jointing, the importance of microgelivation increased and heterogeneous cover deposits, with angular fragments embedded in silty-sandy matrix, originated. In turn, less jointed basalt supported the origin of irregular blocky talus, as on the Muchowskie Wzgórza, rather than sorted scree.

Mid-slope rock spurs (tors) are traditionally considered as periglacial landforms and they have been certainly subject to mechanical weathering, but can be regarded as structural landforms too. Traczyk and Migoń (2003) argued that lithology and structure played a pivotal role in influencing hillslope evolution in the Pleistocene and observations from basalt hills of the West Sudetes support this view. For example, rock cliffs stretching across the slope-frost-riven cliffs according to terminology of cold climate landforms (see French 2007) - are confined to moderately inclined slopes $\left(<15^{\circ}\right)$ and are underlain by basalt colonnades; hence, they are clearly structural features. The same structural predisposition favoured the origin of benches in front of the cliffs - usually considered as cryoplanation terraces, which truncate columns along the horizontal joints (Fig. 4d).

Slope cover deposits are best exposed in quarry walls (Migoń et al. 2002; Maciejak 2010; Fig. 8). On slopes of Mt Wilkołak, slope covers are $2-5 \mathrm{~m}$ thick and occur in a variety of facies, depending on the parent material and local topographic conditions. Most common are heterogeneous deposits, with large (up to $40 \mathrm{~cm}$ ) angular clasts of basalt set within sandysilty matrix. Genetically, they are related to Pleistocene solifluction and have likely formed in several phases, as suggested by clear boundaries between the different units. Other lithological variants of cover beds include open work basalt grus, either fine (clasts up to $10 \mathrm{~cm}$ long) or coarse; bedded grus; massive and laminated silts with occasional basalt clasts; and fine-grained tuff-derived diamictons. Other localities offer fewer possibilities to examine the nature of cover beds because of poor exposure, but the main types listed above are repetitive.

\section{Anthropic Landforms and Human Use}

Natural morphology of basalt hills and tablelands in the Sudetes has been considerably altered by human activities and there are few places where human impact was negligible. Although some interesting natural geomorphic features have probably been lost in this way, long-term quarrying has exposed internal structures of basalt bodies allowing one to examine the relationships between structure and form and reconstruct volcanic processes. Construction activities on and around basalt hills, carried out since the early mediaeval times, left valuable historical legacy which complements natural values and assets.

Historical monuments are of particular interest and these include castles or their ruins, archaeological sites (earth ramparts, moats), chapels and pilgrimage routes, viewing towers and others. Volcanic hills, due to their upstanding position, were valued defensive sites, repeatedly occupied in different periods of history. Amongst the basaltic elevations considered in detail later, a few deserve special mention. The summit surface of $\mathrm{Mt}$ Grodziec - one of the most prominent hills in the region - is occupied by a large castle first built in the mediaeval times and subsequently expanded, then abandoned, but reconstructed in historic style at the turn of the twentieth century. Mt Rataj has a history of human occupation dating back to the seventh-ninth century, followed by a large late mediaeval stronghold with two systems of ramparts and moats. Much more recent quarrying has considerably damaged the archaeological site, but also exposed one of the best examples of columnar jointing in the region. Finally, at Mt Górzec, a pilgrimage site was erected in the eighteenth century at the place of a mediaeval hilltop fort and a Calvary leads to the summit. 
Since the nineteenth century onwards, stone industry developed with different intensities on different hills, resulting in almost complete erasure of morphological form in one place, but leaving only a few minor quarrying sites in another one. Some quarries are long disused, but many are continuously working until today, or exploitation has been resumed recently, as a response to growing economy and widespread road building in particular. Not surprisingly, the hills with the longest history of continuous human activity have their natural morphology considerably altered. Likewise, a few hills have nearly disappeared as a result of quarrying. However, it is generally considered that human activity other than quarrying adds to the overall value of a site if its tangible or intangible evidence is preserved. This standpoint is reflected in the evaluation presented in the following section.

\section{Volcanic Heritage of Pogórze Kaczawskie in the Tourism Industry-Towards Geotourism}

\section{History}

Amongst around 100 volcanic occurrences in the Pogórze Kaczawskie region, about ten fit the working definition of geomorphosites as put forward by Reynard (2009) and these are best suited to be used for the local tourism industry. They are listed in Table 4 (see also Fig. 3). The inventory includes sites whose scenic and/or scientific values have long been appreciated (Birkenmajer 1967), as well as those which are less known, but have a potential to become vital members of a network of volcanic geomorphosites in the region.

Critical analysis of publications focused on tourism in the region reveals that basalt outcrops were long considered as natural curiosities, particularly those exhibiting regular columnar jointing. At Mt Wilkołak, a nature reserve was established in 1959 in the disused part of the quarry, in order to save the complicated arrangement of basalt columns. Unfortunately, the visibility of this structural pattern soon declined considerably due to poor management and uncontrolled vegetation growth, and it was only recently (late 2013) that a largescale vegetation clearance was ordered and the structure of the outcrop exposed again in its full splendour (Fig. 9). Another nature reserve was set up on Mt Ostrzyca in 1962, but here the emphasis was on biological conservation and the walking trail to the top skirts around the most interesting rock cliffs and debris slopes. More specialist literature (Birkenmajer 1967) focuses on past volcanic processes rather than present-day landforms, containing mainly the description of jointing patterns exposed on quarry walls. In the late 1970s, a thematic long-distance hiking trail named the 'The Route of

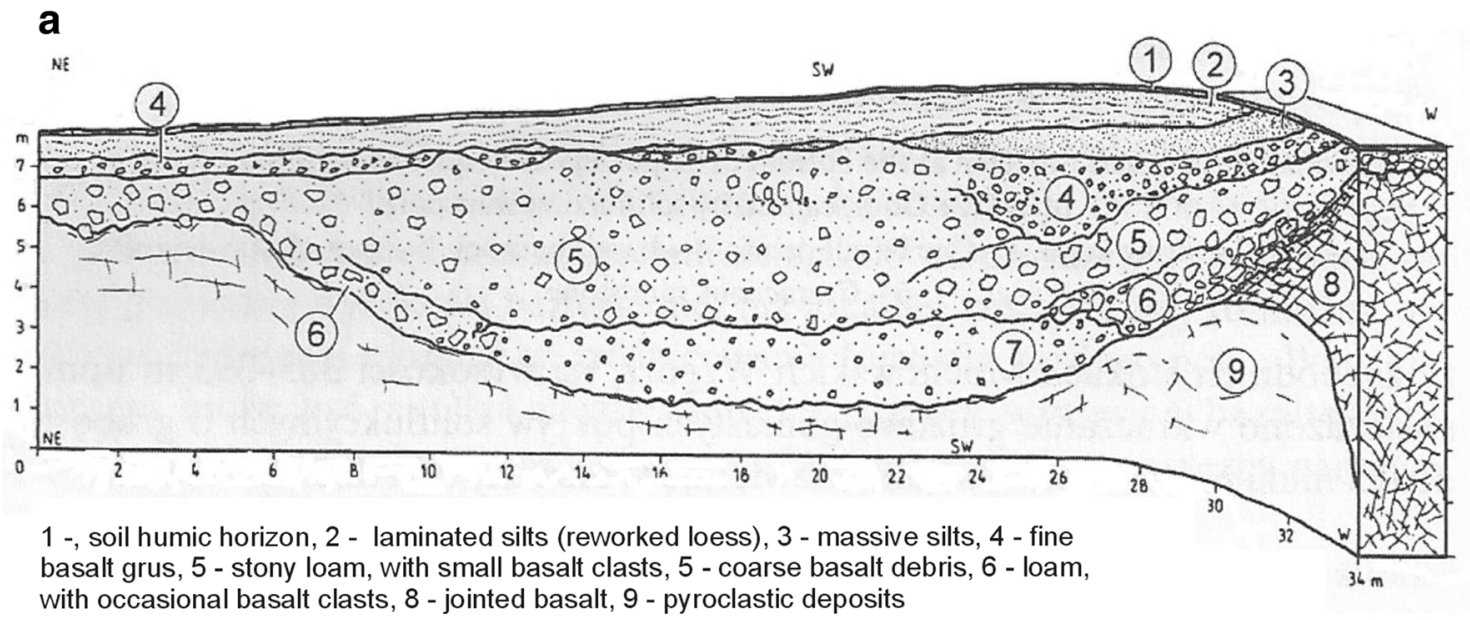

b

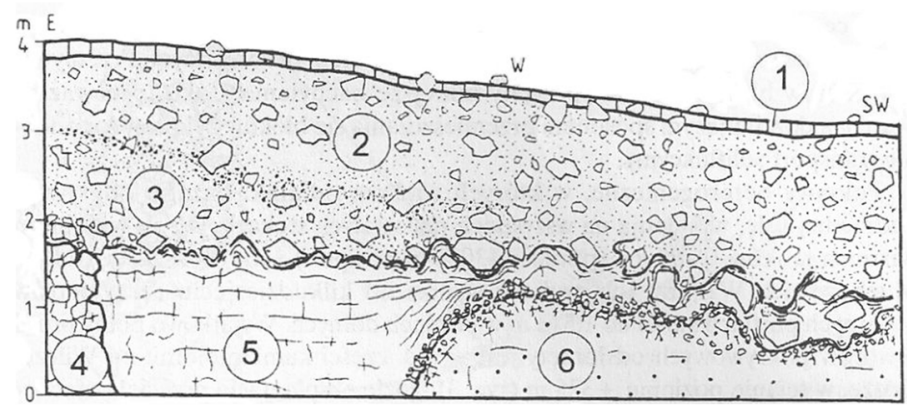

1 - soil humic horizon, 2 - solifluction loam with large basalt clasts, 3 - solifluction loam with small basalt clasts, 4 - basalt bedrock, 5 5 - weathered pyroclastic deposits, 6 Cretaceous sandstones

Fig. 8 a, b Representative sections of Pleistocene cover beds on the slopes of Mt Wilkołak (courtesy K. Maciejak) 
Fig. 9 Examples of recent conservation measures in old basalt quarries, aimed at better exposure of columnar jointing and associated features. $\mathbf{a}, \mathbf{b}$ Geological nature at Mt Wilkołak, before and after vegetation clearance in late 2013. c, d Nature monument at Mt Rataj, before and after vegetation clearance in 2014
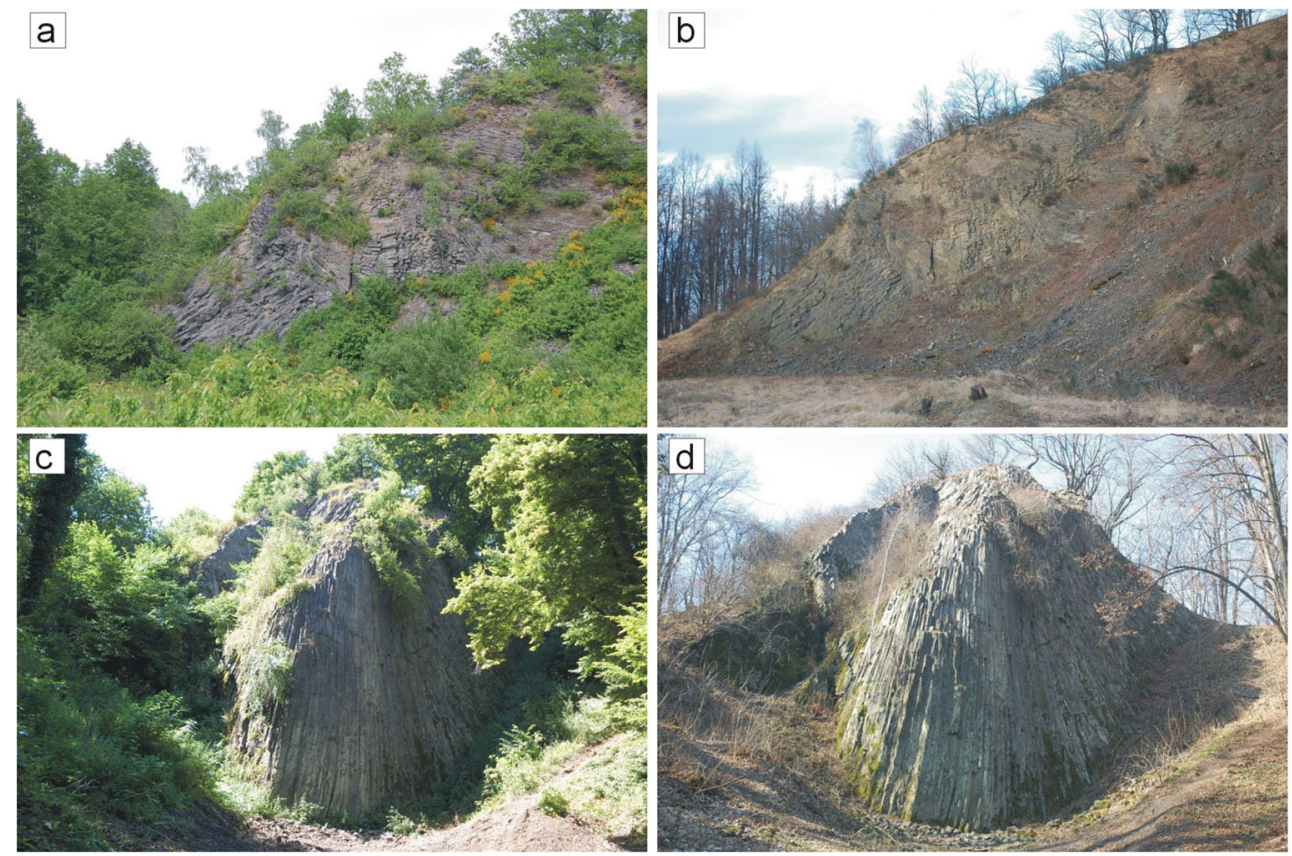

Extinct Volcanoes' was created, but provision of any interpretation facilities necessary to develop geotourism was lacking. In 1992, the 'Chełmy' Landscape Park was established in the eastern part of the Pogórze Kaczawskie, with continued emphasis on geological, including volcanic heritage, but with a limited coverage of geomorphological issues (Grocholski and Wiśniewski 1995).

An increasing interest in regional identity, experienced in Poland in general in the last 20 years or so, coupled with a country-wide increase of community involvement in local affairs, resulted in new initiatives focused on local development. A central role is played by attempts to integrate the promotion of regional geoheritage, in many ways unique in the country due to widespread remnants of volcanism, with the economic development of the area, which is relatively backward and suffers from many of the adverse effects of current economic change. Growth of tourism is regarded as a possible remedy and this is now being promoted by Stowarzyszenie Kaczawskie ('Kaczawa Association'), a local non-governmental organisation. The phrase 'Land of Extinct Volcanoes' has been chosen as a label through which the region would be identified. Despite reservation towards its scientific correctness, as the basalt hills are not strictly volcanoes, the phrase seems a very good choice, since relicts of ancient volcanism are very rare in Poland, and nowhere else do they occur in such a variety and have such aesthetic value as in the Pogórze Kaczawskie.

\section{Recent Developments}

In the last 5 years or so, various activities have been undertaken in the region in order to increase its visibility as a tourist destination in general, and to promote geoheritage-based tourism in particular. They are carried out by Stowarzyszenie Kaczawskie, the 'Chełmy' Landscape Park, and independently by some local players and enthusiasts. For a considerable part of these developments, volcanic heritage is central. Two main directions may be identified. First, it is dissemination of information by means of publications, signage and explanatory boards throughout the region, including consistent use of the phrase 'Land of Extinct Volcanoes' as a regional identifier. Whilst most promotional materials tend to reveal aesthetic values of the landscapes and highlight a diversity of features of tourist interest (natural, cultural, events), a few more specialist publications concerned with geoheritage have also appeared (Bogdański 2006; Migoń 2014). Besides volcanic heritage, remnants of mining activities and mining traditions, which date back to mediaeval times, are identified through publications (Maciejakowie 2006), historical mining trails and annual mass events. New information boards for tourists have been erected, including some dedicated to an explanation of the volcanic history.

Direct geo-education is another field of activity being developed in recent years, although more broadly understood ecological education has been successfully carried out by the 'Chełmy' Landscape Park for more than 20 years. Two specific target groups are schoolchildren and adults living in the region whose understanding of the geoheritage is considered inadequate and/or superficial. A simple model of an exploding volcano, presented on various occasions, remains an attraction for school parties and field classes are focused on rock, mineral and soil recognition. Adult education is accomplished by special short-term courses, invited lectures by professionals, guided tours and educational field trips to nearby regions abroad typified by volcanic remnants (Czech Republic, Germany) to share experience and learn good practice. 
An ambitious project finished recently has been an adaptation of an old traditional farmstead in Dobków-one of the villages in the region - for a centre of regional education within which geoheritage in general and volcanism in particular will be the central themes. The educational offer on site will be complemented by guided and self-guided tours across the region, to visit key geosites, including volcanic.

Despite all these recent advances, a number of challenges remains and these will be discussed, starting from an evaluation of the volcanic geosites.

\section{Evaluation of Volcanic Geosites from a Geomorphological Standpoint}

Further development of geotourism in the region will depend, amongst other factors, on appropriate management of key geosites showing the volcanic legacy and associated geomorphic, as well as cultural features. To assess the value and potential of particular sites, a semi-quantitative evaluation was undertaken. Three groups of features are considered: (a) geomorphological value, including educational potential of a site - as a primary component; (b) added value, arising from the presence of primary volcanic structures and cultural legacy; (c) access, information and management. Whilst devising suitable evaluation procedures, the methodology proposed by Reynard et al. (2007) was consulted, but has been simplified to adjust to the information database available and to avoid subjectivity in numerical scoring (Table 3). In particular, their concept of separate consideration of geomorphological value and added values was adopted, the latter including features of geological interest and cultural legacy. Whilst the primacy of the landform/landscape component over volcanic heritage in a strict sense may seem controversial, it is in accordance with the main purpose of this paper and also echoes the observation by Newsome and Dowling (2005) that scenic landscapes and curiously shaped landforms are usually the main interest amongst the general public. By contrast, the biodiversity component, locally considered very high, was not a part of the assessment of geomorphosites. No additional weighting of criteria was attempted whilst summing up individual scores towards the total value, although Różycka and Migoń (2015) showed that visitors' background and diverse interests may significantly influence their perception of particular geosites.

The evaluation was attempted for ten sites where Cenozoic volcanic rocks crop out (Table 4). Volcanic hills with active quarries have not been considered for two reasons. These sites are off-limits, whereas surface morphological features of potential interest have been completely erased. Mt Wilkołak is a special case (Maciejak 2010). The western side of the hill is an old quarry, protected as a nature reserve. The eastern side hosts an active quarry, which continuously expands towards the reserve, adversely influencing safety conditions and putting the reserve off-limits during blasting. Good outcrops of Pleistocene cover deposits exist in the disused part of the quarrying area, but technically, these are not accessible to visitors and probably will not be until quarry operations cease which is only scheduled in 10 years long perspective.

The highest possible score is 29 points, including 12, 6 and 11 points in each group, respectively. None of the sites approached the maximum, the highest score being 20 for Wilkołak and 18 for Czartowska Skała and Ostrzyca alike. Interestingly, these three sites received 11, 8 and 11 points in the first group (geomorphological value), respectively, but two of them performed rather poorly as far as the third group (access) is concerned, scoring only 5 points. This documents their high or even regionally outstanding value for geomorphology and leaves scope for enhancing the profile of these sites through improved access and better dissemination of information. Values other than geomorphological contribute to the total score in different degrees, from insignificant (less than $15 \%$ of geomorphological value) to very substantial $(100 \%)$. Total scores for access remain in variable relation to scores for geomorphological value, as expressed by a simple ratio which ranges from 2.2 to as low as 0.44 . The former figure characterises two geosites which performed best in the 'geomorphological value' part of the evaluation, scoring 11 out of 12 (Ostrzyca, Wilkołak), but rather poorly in the 'accessibility' part.

However, room for improving access and enhancing the status of each site is not identical. Mt Ostrzyca is far from the nearest parking area and has a conservation status which limits tourist use; hence, the score for accessibility is bound to remain low. By contrast, after quarry operation at Mt Wilkołak ends, its former road infrastructure can be used and interpretation is strengthened; hence, this site may score the maximum number of points. Thus, the results of the evaluation confirm the exceptional position of Wilkołak and may be used to support the idea of an open-air Earth science museum which might replace the quarry after the stone industry finally comes to an end (Maciejak and Gorzkowski 2010). Whilst for most sites the ratio is close to unity, in one case, it is anomalously low ( 0.44 for Bazaltowa). The site is easily accessible and included into an interpretation trail, hence scoring highly in the management group, whilst offering limited experience for geomorphology. However, whilst performing in this way, Mt Bazaltowa provides an example that sites of highest scientific/educational value are not necessarily best suited for geotourism purposes. Notwithstanding the above, the exposed basalt colonnade (Fig. 6) is one amongst the best of its kind in the region.

\section{Challenges}

\section{Sustained Conservation of Volcanic Geosites}

Volcanic sites in the region, including those considered in the evaluation, vary in terms of legal protection (Table 4). Whilst some are listed as nature reserves, others do not have any particular legal status, apart from being located within a landscape park and Natura 2000 area. A few further outcrops, 
Table 3 Criteria to evaluate geomorphosites in the Pogórze Kaczawskie region (authors' own proposal)

\begin{tabular}{|c|c|c|}
\hline Feature & Score & Explanation \\
\hline \multicolumn{3}{|l|}{ Geomorphological value } \\
\hline \multirow[t]{4}{*}{ Legal protection } & 3 & Nature reserve \\
\hline & 2 & Nature monument within Landscape Park \\
\hline & 1 & Site within Landscape Park, but without special designation \\
\hline & 0 & No protection \\
\hline \multirow[t]{3}{*}{ Themes in geomorphology } & 3 & $\begin{array}{l}\text { Three themes present (as discussed in the paper, } \\
\text { "Geomorphological Themes in Cenozoic Volcanism } \\
\text { of the Pogórze Kaczawskie Region" section) }\end{array}$ \\
\hline & 2 & Two themes present \\
\hline & 1 & One theme present \\
\hline \multirow[t]{3}{*}{ Visibility of themes } & 3 & Good outcrops (natural or man-made), good overview of a larger area, visible landmark \\
\hline & 2 & Low natural outcrops, bare block fields, moderate size of an old quarry, visible landmark \\
\hline & 1 & No natural rock outcrops, concealed old quarry, dense vegetation, little surface expression \\
\hline \multirow{3}{*}{$\begin{array}{l}\text { Rareness in relation to the wider } \\
\text { area of SW Poland }\end{array}$} & 3 & Unique site \\
\hline & 2 & Rare site \\
\hline & 1 & Typical site \\
\hline \multicolumn{3}{|l|}{ Added value } \\
\hline \multirow[t]{3}{*}{ Geological value } & 3 & $\begin{array}{l}\text { Three or more themes present (themes considered: [1] columnar jointing, [2] petrological } \\
\text { differentiation, [3] evidence of multiphase development of the volcano, [4] particularly } \\
\text { interesting xenoliths) }\end{array}$ \\
\hline & 2 & Two themes present \\
\hline & 1 & One theme present \\
\hline \multirow[t]{4}{*}{ Cultural heritage } & 3 & Castle \\
\hline & 2 & Spiritual significance, local pilgrimage site \\
\hline & 1 & Old vantage tower, fort relicts, history of development \\
\hline & 0 & None associated \\
\hline \multicolumn{3}{|l|}{ Access } \\
\hline \multirow[t]{3}{*}{ Walking distance from nearest parking } & 3 & $0-15 \min$ \\
\hline & 2 & $15-30 \mathrm{~min}$ \\
\hline & 1 & $30-45 \mathrm{~min}$ \\
\hline \multirow[t]{3}{*}{ Hiking trails } & 2 & Trail across the site \\
\hline & 1 & Site next to a trail, with signposted route of access \\
\hline & 0 & No marked trail in the vicinity or no signposted route of access \\
\hline \multirow[t]{4}{*}{ Availability of information } & 3 & Information board in the field and description in special geotourism publications \\
\hline & 2 & Information board in the field or description in special geotourism publications \\
\hline & 1 & Mentioned in regional publications, including web-based \\
\hline & 0 & No easily accessible information, restricted to specialist publications \\
\hline \multirow[t]{3}{*}{ Restriction to access } & 3 & Unlimited access \\
\hline & 2 & Some restrictions apply (e.g. opening hours) \\
\hline & 1 & Tightly restricted (nature reserve, operating quarry) \\
\hline
\end{tabular}

significant in terms of size and usually opened by large disused quarries, are not protected or managed in any way. Amongst sites selected for evaluation, the intensity of quarrying varied from none/insignificant (Ostrzyca, Górzec, Muchowskie Wzgórza) to widespread (Czartowska Skała, Rataj) and ongoing (Wilkołak). Whilst quarrying activity may help to better expose the internal structures of volcanic edifices, it is destructive for any geomorphological values as well as the scenic attributes of the landscape. In fact, the 'volcanic' silhouettes of several basalt hills (e.g. Wilkołak, Czartowska Skała) have been artificially sharpened by slope undercutting, whereas their original (i.e. pre-quarrying) morphology would have been more subdued. It may only be speculated whether the slopes of Mt Wilkołak abounded with 


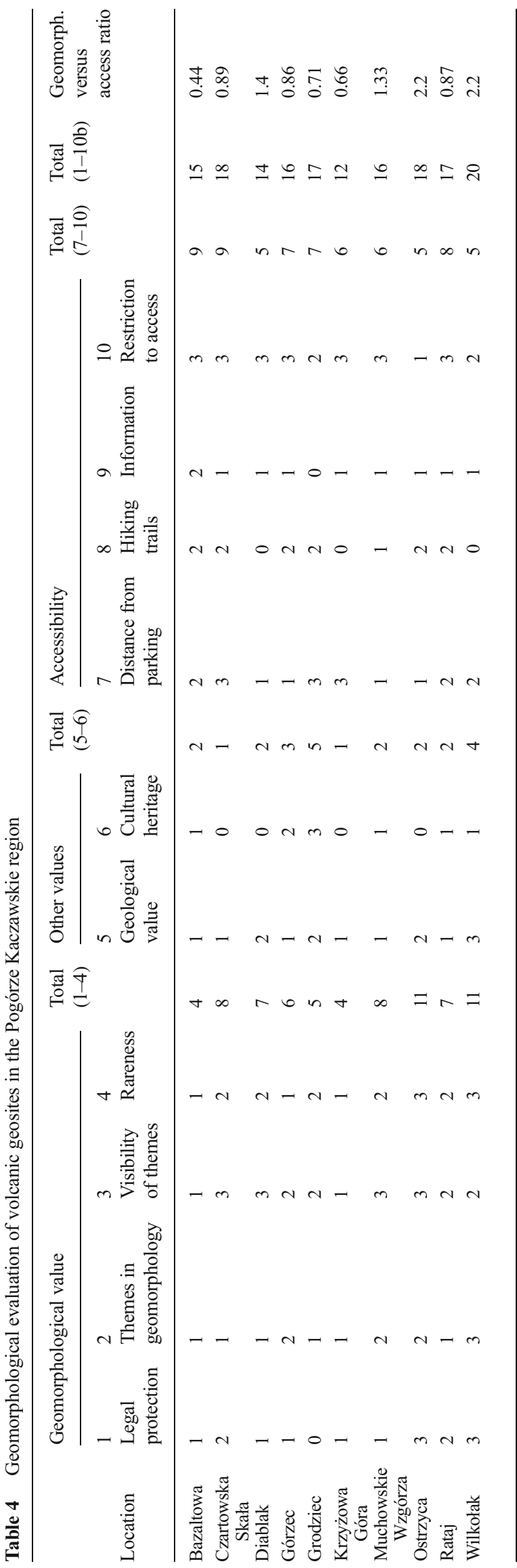

basalt cliffs and block fields in a way similar to what can be now seen on Mt Ostrzyca. There are descriptions of 'ice caves' in basalt at Mt Łysanka in local journals from the 1930 s, from an area that has been taken over by a huge quarry expansion. It is probable that a valuable, seemingly unique component of local geoheritage was irreversibly lost.

The threat for geomorphological integrity of the evaluated sites from resumed/expanded quarrying appears minor, except for Mt Wilkołak where it will continue for the next decade or so. The location of other sites within protected areas seems to provide sufficient safeguarding against the development of industry, particularly since there are much larger documented basalt resources elsewhere in the region.

A more immediate threat to the visibility of volcanic geoheritage is poor management of individual sites. This is particularly acute for rock walls and talus slopes in disused quarries which can be quickly overwhelmed by vegetation, obscuring both volcanic structures themselves and the wider geomorphic context (Różycka and Migoń 2015). Outcrops of Quaternary hillslope deposits, indicative of degradation of volcanic structures in the cold climate, suffer most. Fortunately, the awareness of the value of volcanic geoheritage has grown recently, and controlled vegetation clearance at a few sites (Wilkołak, Rataj) has been carried out (Fig. 9). Nevertheless, long-term management plans are needed to ensure sustained visibility and accessibility. Whilst nature reserves are required by law to have such management plans, sites classified as nature monuments are not and it is effectively up to the local authorities whether adequate measures are implemented or not.

A special case in this study is Mt Ostrzyca which is the only site hardly affected by human activities. Therefore, it is of considerable value from the standpoint of biological conservation and has been protected as nature reserve since 1962 . Whilst this status provides the most effective protection of the hill in the long-term, it also- due to associated regulationshas effectively put off-limits its geomorphologically most interesting parts. Unique basalt scree slopes, impressive midslope crags and ravines, as well as evidence of recent encroaching of scree on trees below cannot be visited except from one vantage point offering rather limited insights, although non-permitted visits do take place.

Vandalism is another issue, but most of it is directed towards elements of infrastructure (information boards, signage, resting areas) rather than geological or geomorphological features themselves, although some outcrop defacing does take place. This observation directly bears on strategies of effective interpretation, as discussed below.

\section{Interpretation}

It is widely acknowledged that adequate interpretation is essential for both raising awareness of geoheritage beyond the professional circles as well as successful geotourism (e.g. Hose 2005; 
Hughes and Ballantyne 2010; Crawford and Black 2012). In the specific geographical context of the Pogórze Kaczawskie region, a range of challenges may be identified, particularly evident if the geomorphological component is to be explored.

First, not very much is known about the original morphology of volcanic landforms, and hence, it is difficult to relate the contemporary landforms to the Oligocene and Miocene volcanoes and assess the magnitude of landform change. Thus, only a general, textbook-like explanation can be offered. Whilst this uncertainty may not be of too much concern for interested/aware visitors (terminology from Dowling 2011 is used), geo-experts may be disappointed by a too general explanation. Second, some basalt hills have a misleading superficial appearance, resembling true volcanic cones, whereas they are not. However, the phrase 'extinct volcanoes' has long been used for this part of the Sudetes to underline its rarity and seems an effective means to capture attention of the public whose knowledge of geoscience is generally very limited. In consequence, any interpretation faces a dilemma at which stage and how to correct this view and how much of scientific accuracy can be sacrificed. Third, the choice of terminology needs to be decided with care, since whilst the term 'volcano' is universally understood, the term 'neck' for an exposed volcanic vent is very technical. Likewise, several terms to describe cold climate geomorphic legacy present on slopes of basalt hills, if given without proper explanation, will not be understood. Although this problem can be easily overcome during a longer guided tour or talk, it remains critical for the readability of information boards and short leaflets. Fourth, regular columnar jointing is the feature that first captures visitors' attention and there is a risk that it will overshadow other, less visually evident aspects of volcanic heritage, especially if time for a visit is limited. Little understanding would be gained in effect.

Another group of challenges, but also opportunities, is related to the broader context of past volcanism in the Pogórze Kaczawskie region. For reasons only partially known, the volcanic hills are rather low and subdued, except for a few cases. At the same time, not far away ( $2-3 \mathrm{~h}$ drive) one can see far more impressive remnants of Cenozoic volcanoes in the near-border areas of Lausitz, Germany, and especially in the northern part of the Czech Republic. Thus, whilst the area can claim uniqueness in Poland, its significance diminishes if the wider geographical environment is concerned. However, this comparison may also be used as an advantage and the volcanic ruins in SW Poland presented as a part of general story of lifetimes of volcanoes. Then, the other necks would not be 'better' but simply 'different'.

Finally, volcanic heritage alone, and especially postvolcanic geomorphology, is probably not enough to support long-term successful geotourism. It is a part of a wider story which should be integrated with interpretation of Cenozoic volcanism and its remnants. Unexplored or poorly explored themes are the changing human use of volcanic rocks through time, relation to other periods of volcanism in the region, and the history of climate change through geological time.

\section{Further Geotourism Development}

Notwithstanding the challenges associated with interpretation, it is hypothesised that the Pogórze Kaczawskie region is well suited to develop its tourist product based on geoheritage. In this context, the following recommendations can be offered for geotourism initiatives to be successful:

- Sustained geo-education of local leaders, including study visits abroad, so that the unique value of Earth heritage is realised and codes of good practice applied elsewhere can be transferred.

- Sustained collaboration with academic circles, not only in the field of geoscience, but also tourism and regional marketing.

- Development and improvement of existing means of communication with the general public, following the findings of Crawford and Black (2012) that information boards alone do not always play an intended role.

- Development of infrastructure next to volcanic (and other) geosites. The results of evaluation show that there is a significant room for improvement.

- Monitoring of visitors' satisfaction and constant adjustments of interpretative facilities.

- Realising that 'geotourism' and 'geoheritage' (their Polish translations) are not well understood concepts, emphasis on specific features (e.g. volcanoes) or more general scenic values of the landscape is probably more promising.

- Likewise, whilst advertising the region on the tourist market, linkages between geoheritage and other types of heritage should be stressed, since the visual expression of past volcanism and its scientific and educational values are not obvious at first sight and surely not to people with limited initial interest in geoheritage.

- Increasing collaboration with other regions where volcanic heritage is used as the main asset and driver of tourism development.

\section{Conclusions}

General public interest in volcanic heritage is usually limited to volcanic processes and landforms arising directly from eruptive or effusive activity. Oligocene to Miocene volcanism in the West Sudetes was sufficiently distant in time that the original volcanic constructions have been erased by subsequent denudation. Nevertheless, this subsequent degradation has left a suite of landforms which may play an important role as sites of geomorphological interest. At least three geomorphological themes may be explored revealing how volcanism influences and interplays with landscape development in the long-term.

Firstly, volcanic rocks are invariably connected with residual landforms, allowing for the evaluation of senile stages of volcano degradation and the influence of strength differences between 
volcanic and country rock. At a local scale, details of hillslope morphology are controlled by rock mass strength properties and patterns of columnar jointing. Thus, referring to general landform classifications in geomorphology, basalt hills of the Pogórze Kaczawskie area represent a transition between volcanic and structural landforms. Secondly, occurrences of volcanic rocks may be used as markers of long-term denudation, both qualitatively and quantitatively. Thirdly, the specific geomorphic history of the West Sudetes opens a further avenue of research, namely how the different materials of volcanic origin responded to periglacial conditions of the Pleistocene. Another theme, not yet explored in any depth, is the interplay with ice sheet advances and decays.

The concept of geomorphosites underlines the presence of added values, arising from cultural significance of geomorphological localities. Residual volcanic landforms, by virtue of their isolation from the surrounding landscape, have attracted human interest since mediaeval times. In the West Sudetes, nearly every volcanic hill has a history of human presence and carries its material legacy. Amongst them are imposing castle ruins, as well as more subtle elements such as remnants of hilltop forts or ancient border stones. Hence, these landforms are particularly suited to illustrate various interactions between geomorphology and people.

The potential of the best sites in the Pogórze Kaczawskie area is yet to be fully utilised by local tourism industry, although many recent initiatives need to be acknowledged. The main challenges include (1) appropriate translation of the accumulated scientific knowledge into the form accessible to the general public, (2) successful dissemination of this information to complement existing appreciation of historical and ecological values of the sites and (3) implementation of adequate management plans for the most important sites, so that their scenic and scientific qualities do not disappear due to either human activity or uncontrolled vegetation growth.

Acknowledgments Thanks are foremost directed to Ewelina and Krzysztof Rozpędowscy, for providing support, information and opportunity to join the local initiatives. Gabriela Męczyńska and Mariusz Foryś from NGO Stowarzyszenie Kaczawskie were always willing to share experience and information. We are also grateful to Kinga and Krzysztof Maciejak for their help and assistance in our geomorphological and tourism studies of ancient volcanic terrains in the West Sudetes.

Open Access This article is distributed under the terms of the Creative Commons Attribution 4.0 International License (http:// creativecommons.org/licenses/by/4.0/), which permits unrestricted use, distribution, and reproduction in any medium, provided you give appropriate credit to the original author(s) and the source, provide a link to the Creative Commons license, and indicate if changes were made.

\section{References}

Alexandrowicz Z, Kućmierz A, Urban J, Otęska-Budzyń J (1992) Waloryzacja przyrody nieożywionej obszarów i obiektów chronionych w Polsce (Engl. summ. Evaluation of inanimate nature of protected areas and objects in Poland). Państwowy Instytut Geologiczny, Warszawa (in Polish)

Awdankiewicz M (1999) Volcanism in a late Variscan intramontane trough: Carboniferous and Permian volcanic centres of the intraSudetic Basin, SW Poland. Geol Sudet 32:13-47

Awdankiewicz M (2005) Reconstructing an eroded scoria cone: the Miocene Sośnica Hill volcano (Lower Silesia, SW Poland). Geol Q 49:439-448

Badman T (2010) World Heritage and geomorphology. In: Migoń P (ed) Geomorphological landscapes of the world. Springer, Dordrecht, $\mathrm{pp}$ 357-368

Badura J, Przybylski B (1998) Zasięgi lądolodów plejstoceńskich i deglacjacja obszaru między Sudetami a Wałem Śląskim (Engl. summ. Extent of the Pleistocene ice sheets and deglaciation between the Sudeten and the Silesian Rampart). Biul Inst Geol 385:9-28

Badura J, Przybylski B (2004) Dolnośląska formacja bazaltowa (Lower Silesian basaltic province). In: Peryt TM, Piwocki M (eds) Budowa geologiczna Polski, vol I, part 3a. Państwowy Instytut Geologiczny, Warszawa, pp 161-168 (in Polish)

Badura J, Przybylski B, Zuchiewicz W (2004) Cainozoic evolution of Lower Silesia, SW Poland: a new interpretation in the light of subCainozoic and sub-Quaternary topography. Acta Geodyn Geomater 1, 3(135):7-29

Badura J, Pécskay Z, Koszowska E, Wolska A, Zuchiewicz W, Przybylski B (2005) New age and petrological constraints on Lower Silesian basaltoids, SW Poland. Acta Geodyn Geomater 2, 3(139):7-15

Badura J, Zuchiewicz W, Štěpančiková P, Przybylski B, Kontny B, Cacoń S (2007) The Sudetic Marginal Fault: a young morphotectonic feature at the NE margin of the Bohemian Massif, Central Europe. Acta Geodyn Geomater 4(4):7-29

Baraniecki L (1951) Gołoborza Ostrzycy i Sobótki (Bare blockfields of Ostrzyca and Sobótka). Czas Geogr 21(22):439-440 (in Polish)

Birkenmajer K (1967) Bazalty dolnośląskie jako zabytki przyrody nieożywionej (Engl. summ. Lower Silesian basalts as monuments of inanimate nature). Ochrona Przyrody 32:225-276

Birkenmajer K, Pécskay Z, Grabowski J, Lorenc MW, Zagożdżon P (2007) Radiometric dating of the Tertiary volcanics in Lower Silesia, Poland. V. K-Ar and palaeomagnetic data from Late Oligocene to Early Miocene basaltic rocks of the North-Sudetic depression. Ann Soc Geol Pol 77:1-16

Blecha M, Burliga S, Lojka R, Martinek K, Wojewoda J (2008) Osady permskie basenu śródsudeckiego (Permian sediments of the IntraSudetic Basin). In: Baseny Śródgórskie: kontekst regionalny środowisk i procesów sedymentacji. Polska Konferencja Sedymentologiczna, Kudowa Zdrój, 15-21.09.2008, pp 61-83

Bogdański J (2006) Geologiczny raj Krainy Wygasłych Wulkanów (Geological paradise of the Land of Extinct Volcanoes). Stowarzyszenie Kaczawskie, Mściwojów (in Polish)

Boivin P, Thouret JC (2013) The volcanic Chaîne des Puys: a unique collection of simple and compound monogenetic edifices. In: Fort M, André MF (eds) Landscapes and landforms of France. Springer, Heidelberg, pp 81-91

Büchner J, Tietz O (2013) Reconstruction of the Landeskrone Scoria Cone in the Lusatian volcanic field, Eastern Germany - insights on a large sized monogenetic volcano, long-lasting degradation of volcanic edifices and implications for the landscape evolution. Geomorphology 151-152:175-187

Crawford KR, Black R (2012) Visitor understanding of the geodiversity and the geoconservation value of the Giant's Causeway World Heritage site, Northern Ireland. Geoheritage 4:115-126

Cwojdziński S, Jodłowski S (1982) Plamowe koncentracje bazaltowe Masywu Czeskiego i Dolnego Śląska (Engl. summ. "Stained" basaltic concentrations of the Bohemian Massif and the Lower Silesia). Biul Inst Geol 341:201-229 
Day MJ, Goudie AS (1977) Field assessment of rock hardness using the Schmidt test hammer. Br Geomorph Res Group Tech Bull 18:19-29

Dingwall P, Weighell T, Badman T (2005) Geological World Heritage: a global framework. IUCN, Gland

Dohrenwend JC, Wells BD, Turrin BD (1986) Degradation of Quaternary cinder cones in the Cima volcanic field, Mojave Desert, California. Geol Soc Am Bull 97:421-427

Dowling RK (2011) Geotourism's global growth. Geoheritage 3:1-13

Erfurt-Cooper P (2010) Geotourism - active geothermal and volcanic environments as tourist destinations. In: Dowling R, Newsome D (eds) Global geotourism perspectives. Goodfellow, Oxford, pp 33-48

Erfurt-Cooper P (ed) (2014) Volcanic tourist destinations. Springer, Heidelberg

French HM (2007) The periglacial environment. Wiley, Chichester

Gao W, Li J, Mao X, Li H (2013) Geological and geomorphological value of the monogenetic volcanoes in Wudalianchi National Park, NE China. Geoheritage 5:73-85

Gawlikowska E (2000) Ochrona georóżnorodności na Dolnym Śląsku (Geodiversity conservation in Lower Silesia). Państwowy Instytut Geologiczny, Warszawa (in Polish)

Grocholski A, Jerzmański J (1975) Zabytki paleowulkanizmu na Dolnym Śląsku w świetle ochrony przyrody (Engl. summ. Paleovolcanic occurrence in the Lower Silesia in the light of nature protection). Ochrona Przyrody 40:291-340

Grocholski A, Wiśniewski E (1995) Przewodnik geologiczny po Parku Krajobrazowym Chełmy na Pogórzu Kaczawskim (Geological guidebook of the Chełmy Landscape Park in the Pogórze Kaczawskie). Państwowy Instytut Geologiczny, Wrocław (in Polish)

Hall AM (1991) Pre-Quaternary landscape evolution in the Scottish Highlands. Trans R Soc Edinb Earth Sci 82:1-26

Hill IG, Worden RH, Meighan IG (2001) Formation of interbasaltic laterite horizons in NE Ireland by early Tertiary weathering processes. Proc Geol Assoc 112:339-348

Hose TA (2005) Geotourism and interpretation. In: Dowling R, Newsome D (eds) Geotourism. Elsevier Butterworth-Heinemann, Oxford, pp 221-241

Hughes K, Ballantyne R (2010) Interpretation rocks! Designing signs for geotourism sites. In: Newsome D, Dowling RK (eds) Geotourism: the tourism of geology and landscape. Goodfellow, Oxford, pp 184 199

Ihnatowicz A, Koźma J, Wajsprych B (2011) Wałbrzyski Obszar Geoturystyczny - inwentaryzacja geotopów dla potrzeb promocji geoturystyki (Engl. summ. Wałbrzych Geoturist area - inventory of geotopes for promotion of geotourism). Przegl Geol 59:722-731

Inbar M, Lugo Hubp J, Villers Ruiz L (1994) The geomorphological evolution of the Paricutin cone and lava flows, Mexico, 19431990. Geomorphology 9:57-76

Karátson D (1996) Rates and factors of stratovolcano degradation in a continental climate: a complex morphometric analysis of nineteen Neogene/Quaternary crater remnants in the Carpathians. J Volcanol Geotherm Res 73:65-78

Karátson D, Csontos L, Szabolcs H, Székely B, Kovácsvölgyi S (2001) Volcanic successions and the role of destructional events in the Western Mátra Mountains, Hungary: implications for the volcanic structures. Géomorphologie Relief, Processus, Environnement 2001(2):79-92

Kopecký L (1978) Neoidic taphrogenic evolution and young alkaline volcanism of the Bohemian Massif. Sbor Geol Věd A 31:91-104

Kosiór A (2004) Exceptional geodiversity of the Intra-Sudetic Basin within the landscape of the Upper Ścinawka river drainage area. Polish Geol Inst Spec Pap 13:57-64

Maciejak K (2010) Wilkołak jako element środkowoeuropejskiej prowincji wulkanicznej (Engl. summ. Geology). In: Gorzkowski R (ed) Wilkołak (Wilcza Góra) koło Złotoryi. Geologia - przyroda - historia. Towarzystwo Miłośników Ziemi Złotoryjskiej, Złotoryja, pp $11-42$

Maciejak K, Gorzkowski R (2010) Rezerwat przyrody Wilcza Góra i jego rola w edukacji przyrodniczej i regionalnej (Engl. summ. The Wilcza Góra nature reserve and its role in environmental and regional education). In: Gorzkowski R (ed) Wilkołak (Wilcza Góra) koło Złotoryi. Geologia - przyroda - historia. Towarzystwo Miłośników Ziemi Złotoryjskiej, Złotoryja, pp 135-165

Maciejakowie KK (2006) Na tropach dawnego górnictwa Gór i Pogórza Kaczawskiego (Following mining heritage in the Góry and Pogórze Kaczawskie region). GoldCentrum, Złotoryja (in Polish)

Migoń P (2014) Geotouristic attractions of the Land of Extinct Volcanoes. Stowarzyszenie "Lokalna Grupa Działania Partnerstwo Kaczawskie", Mściwojów

Migoń P, Łach J (1998) Geomorphological evidence of neotectonics in the Kaczawa sector of the Sudetic Marginal Fault, southwestern Poland. Geol Sudet 31:307-316

Migoń P, Maciejak K, Zygmunt M (2002) Peryglacjalna rzeźba wzgórz bazaltowych Pogórza Kaczawskiego (Sudety Zachodnie) i jej znaczenie dla paleogeografii plejstocenu (Engl. summ. Periglacial morphology of basalt hills in the Kaczawa Upland (Western Sudetes)). Prz Geogr 74:491-508

Moufti MR, Németh K (2013) The intra-continental Al Madinah Volcanic Field, Western Saudi Arabia: a proposal to establish Harrat Al Madinah as the first volcanic geopark in the Kingdom of Saudi Arabia. Geoheritage 5:185-206

Németh K (2001) Long-term erosion-rate calculation from the Waipata volcanic field (New Zealand) based on erosion remnants of scoria cones, tuff rings and maars. Géomorphologie Relief, Processus, Environnement 2001(2):137-152

Németh K, Martin U (1999) Late Miocene paleo-geomorphology of the Bakony-Balaton Highland Volcanic Field (Hungary) using physical volcanology data. Z Geomorphol 43:417-438

Newsome D, Dowling R (2005) The scope and nature of geotourism. In: Dowling R, Newsome D (eds) Geotourism. Elsevier, Amsterdam, pp 3-25

Ollier CD (1969) Volcanoes. Australian National University Press, Canberra

Panizza M, Piacente S (2009) Cultural geomorphology and geodiversity. In: Reynard E, Coratza P, Regolini-Bissig G (eds) Geomorphosites. Verlag Dr. Friedrich Pfeil, München, pp 35-48

Piasecki H (1956) Morphologie périglaciaire du bord des Sudetes aux environs de Jawor. Biul Peryglac 4:277-283

Placek A (2007) Basaltic hills as structural landforms - morphometry versus rock strength (a study from the Kaczawskie upland, SW Poland). Universitatis Ostravensis Acta Fac Rer Nat 237, Geographia - Geologia 10:111-127

Placek A, Migon P (2007) Rock-landform relationships in the Sudetes in the light of rock strength assessment using the Schmidt hammer. In: Goudie AS, Kalvoda J (eds) Geomorphological variations. Nakl P3K, Prague, pp 287-311

Puziewicz J, Koepke J, Grégoire M, Ntaflos T, Matusiak-Małek M (2011) Cenozoic rifting in Central Europe: evidence from the Ksieginki nephelinite (SW Poland) xenolith suite. J Petrology 52:2107-2145

Rapprich V, Cajz V, Košták M, Pécskay Z, Ř́dkošil T, Raška P, Radoň M (2007) Reconstruction of eroded monogenic Strombolian cones of Miocene age: a case study on character of volcanic activity of the Jičín Volcanic Field (NE Bohemia) and subsequent erosional rates estimation. J Geosci 52:169-180

Reicherter K, Froitzheim N, Jarosiński M, Badura J, Franzke HJ, Hansen M, Hübscher C, Müller R, Poprawa P, Reinecker J, Stackebrandt W, Voigt T, von Eynatten H, Zuchiewicz W (2008) Alpine tectonics north of the Alps. In: McCann T (ed) The geology of central Europe, Vol 2. Mesozoic and Cenozoic. Geological Society of London, Bath, pp 1233-1286 
Reynard E (2009) Geomorphosites: definitions and characteristics. In: Reynard E, Coratza P, Regolini-Bissig G (eds) Geomorphosites. Verlag Dr. Friedrich Pfeil, München, pp 9-20

Reynard E, Fontana G, Kozlik L, Scapozza C (2007) A method for assessing "scientific" and "additional values" of geomorphosites. Geogr Helv 62:148-158

Różycka M, Migoń P (2015) Visitors' background as a factor in geosite evaluation. The case of Cenozoic volcanic sites in the Pogórze Kaczawskie region, SW Poland. Geotourism (in press)

Śliwa Z (1967) Własności strukturalne bazaltów Ślaska (Engl. summ. Structures in Silesian basalts). Rocznik Pol Towarz Geol 37:435454

Smith BJ, McAlister JJ (1987) Tertiary weathering environments and products in north-east Ireland. In: Gardiner V (ed) International geomorphology 1986, part II. Wiley, Chichester, pp 1007-1031

Thouret JC (1999) Volcanic geomorphology-an overview. Earth-Sci Rev 47:95-131
Tietz O, Gärtner A, Büchner J (2011) The monogenetic Sonnenberg scoria cone-implications for volcanic development and landscape evolution in the Zittauer Gebirge Mountains since the Paleogene. Z Geol Wiss 39:311-334

Traczyk A, Migoń P (2003) Cold-climate landform patterns in the Sudetes. Effects of lithology, relief and glacial history. Acta Univ Carol Geogr 35(Suppl 2000):185-210

Walczak W (1968) Sudety. PWN, Warszawa (in Polish)

Wocke MF (1927) Der Basalt in der Schlesischen Landschaft. Veröffentlichungen der Schlesischen Gesellschaft für Erdkunde 5: $1-51$, Breslau

Wood C (2009) World Heritage volcanoes: thematic study. IUCN, Gland Ziegler P, Dèzes P (2007) Cenozoic uplift of Variscan Massifs in the alpine foreland: timing and controlling mechanisms. Global Planet Change 58:237-269

Zimmermann E, Kühn B (1936) Erläuterungen zu Blatt Goldberg und Schönau. Geologische Karte von Preußen. Lieferung 292

Zuchiewicz W, Badura J, Jarosiński M (2007) Neotectonics of Poland: an overview of active faulting. Studia Quat 24:5-20 